\title{
The Conceptual Basis of the Priority of the Authorized Agency Compared to Creditors in Bankruptcy: A Generalization of the International Experience of Regulation of Fiscal Relation in Cases of Bankruptcy of the Taxpayer ${ }^{*}$
}

\author{
S. S. Izvekov \\ The Ural State Law University, \\ 21, Komsomolskaya ul., Yekaterinburg, 620137, Russian Federation
}

For citation: Izvekov, Stanislav S. The Conceptual Basis of the Priority of the Authorized Agency Compared to Creditors in Bankruptcy: A Generalization of the International Experience of Regulation of Fiscal Relation in Cases of Bankruptcy of the Taxpayer. Vestnik of Saint Petersburg University. Law 3: 491-519. https://doi.org/10.21638/spbu14.2019.306

The subject of the study is the relation between tax legislation and bankruptcy legislation. The selected theme is seen sporadically in the analysis of certain issues in the framework of regulating legal relations arising in bankruptcy cases. The object of our study will be the public relations arising in the performance of the organization of tax liabilities of the bankrupt at the expense of property, including property pledged as collateral. Our objective was to attempt to overcome the existing gap in the legal regulation of the status of an authorized body as a mortgage lender, filling in the gaps in national law and harmonizing it with the legislation of other nations. In addition, the present work highlights the prospects of setting tax issues in cross-border bankruptcy cases on the example of the BRICS countries. We formulate the basic contradictions in the ratio of priority tax claims in the federal law of BRICS countries, assess the situation, direct state involvement in bankruptcy cases in other states, and outline ways of overcoming problems. The work used the comparative method in accordance with examples of cross-border bankruptcies that the national bankruptcy legislation adopted in BRICS countries. A proposal is made for granting the competent authority the same rights of secured creditors if the requirements about payment of obligatory payments are secured by a pledge of property of the taxpayer. The author also confirmed the divergence of national legislation on the ranking of creditors in some of the BRICS countries. In addition, we provide preconditions for the participation of the competent authorities of some countries in proceedings instituted in the territory of the other BRICS countries. The author made recommendations for the improvement of tax legislation and bankruptcy law which will also ensure the fiscal interests of the state.

Keywords: transboundary insolvency, cross-border insolvency, tax issues, obligatory payment, competition of international claims, equality of rights, authorized agency, the lender, the security of property, priority of claims.

* The article was prepared in the framework of the state task of the Ministry of education and science of Russia, code of the project: 26.12267.2018/12.1.

() Санкт-Петербургский государственный университет, 2019 


\section{The basic principle of priority of creditors in the bankruptcy legislation in Russian Federation}

For a long time there is a debates about the priority of state tax claim and private claims in bankruptcy cases.

One of the arguments for the priority is state claims is a theory "state - involuntary creditor of an insolvent debtor".

This conception is worth to be researched because for a long time it was used as a basic model for priorities of creditors of an insolvent debtor (for example, in UK, Germany, France, Italy, Spain, Australia, New Zealand, Canada, US, Mexico, China, Brazil, India and some other countries). After these countries shifted from the conception of "involuntary creditor" to pursue economic aims, as they made assumption that creditors of the insolvent debtor can receive much more, and this support would enable to receive much more taxes.

This conception was not reflected in Russian legal literature and was not used in legislation. Russian competition law was based on other principles - the priority of public claims serves for the security of common wealth. At a later stage as a result of a reform public claims were equated with claims of private creditors, but this change was based not on the economic aims, but in connection with new introduced powers and mechanism to withhold tax debts.

Reformation period is still pending as the Federal Assembly of the Russian Federation receives new projects for changes of the creditors' order of priorities ${ }^{1}$. Moreover, the order established by the Article 134 of the Insolvency Act differs from the common rules of Articles 64, 65, 855 of the Civil Code of Russian Federation.

Also in the legal doctrine there are views for the changing of present order of creditors' priorities for the benefit of the state (Igolkina 2013; Laskina 2009).

Furthermore, sometimes new already existed in the past. The roots of bankruptcy institute are coming from Russkaya Pravda (consolidation of rules $13-14^{\text {th }}$ cent.), Sobornoye Ulozhenie (the Council Code of 1649), and the development of it in the Statute of bankrupts (19.12.1800), Statute of the market insolvency (23.06.1832) and following projects of the codification acts (Shershenevich 1890,67). Traditionally tax claim of the state prevailed over private claims. The Decree of All-Russian Central Executive Committee and the Council People's Deputies 28.11.1927 in Civil Procedural Code was added a new rule that exclude private interests claims in bankruptcy cases (Dobrovol'skii 1927, 156).

The Russian Federation Law "On insolvency of business entities" 19.11.1992², the Federal Law "On insolvency (bankruptcy)" $08.01 .1998^{3}$ established the priority of public claims in bankruptcy cases.

\footnotetext{
1 Passport of the project of the Federal law No. 727385-6 "On amendments to article 137 of the Federal law "On insolvency (bankruptcy)" submitted by the deputies of the State Duma of the Federal Assembly of the Russian Federation Sergey Gavrilov, A. V. Surkovym, a member of the Federation Council of the Federal Assembly of the Russian Federation A. V. Belyakov (withdrawn).

2 Insolvency (bankruptcy) of enterprises: the Law of the Russian Federation dated 19.11.1992 No. 3929-1 // Rossiyskaya gazeta, No. 279, 30.12.1992.

3 Insolvency (bankruptcy): Federal law of 08.01.1998 No. 6-FZ // Sz RF, 12.01.1998, No. 2, p. 222.
} 
In the present time there is a third bankruptcy law ${ }^{4}$, and in its concept note ${ }^{5}$ was explained the changing of the status of tax organs in bankruptcy cases (Vitrianskii 2003, 3).

The arguments for the equality between state organs and private claims were in admission of not sufficient protection of rights and legal interest of the government, and use of bankruptcy institute as an instrument for tax evasion (Goncharov 2010; Radygina 2005; Kasnitskaia 2008).

The Property Committee ${ }^{6}$ and Legal Management ${ }^{7}$ of the State Duma positively characterized new rules of 2002, admitting the before existing loopholes.

The necessity of priority of public claims usually is reasoned by the defense of public interests that cannot be compared with private interests of private structures. State budget plays universal functions, which influence all citizens. Budgetary funds provide public security, social protection for particular groups. "The rule which equates public and private interests invokes many questions” (Rossiyskaya gazeta. 07.08.2002).

As a result of a research was done conclusion, that a state, losing its priority for getting its money, but receiving voting right, can increase chances to collect taxes (Bekker 2002). Classification criterion which identifies certain privileged creditors, is based on the social value of secured interest. Many authors positively evaluated the new rule, mentioning its positive influence for the balance of private and state interests in competition relations, arguing for the equality of private creditors and authorized organs. Among those are Khimichev V. A. (Khimichev 2005, 18), Borisenkova T.V. (Borisenkova 2008; Borisenkova 2017), Brezho M. A. (Brezho 2005). Studentsova O.A. also notes that "this principle is fully in accordance with the equality of civil law relations (Article 1.1 the Civil Code of Russia), and provisions of Article 124 of the Civil Code that subjects of public entities are equal with private ones in civil relations" (Studentsova 2006).

The abovementioned legal initiatives and views of the researches very rarely use foreign practice and doctrinal works of foreign authors for the priority problem solving.

Hence, the priority of the state claims in bankruptcy cases due to the theory "State involuntary creditor of an insolvent debtor" is not impossible.

\section{The concept "State is an involuntary creditor of the insolvent debtor"}

This conception is based on the following arguments. In contrast with private creditors, tax organs are involuntary creditors as they do not choose their contractor before it becomes a debtor or receive secured guarantee before the debt. In accordance with present conception a state does not have an ability to choose, evaluate the reliability of a contractor and ends up in the involuntary situation. The state is not guaranteed for the situation of abusive behavior of a debtor for the purpose of abuse of law or tax evasion. The legal connection between tax creditor and tax debtor is connected with a construction of tax obligation, where private subject of law is a priory a debtor for tax claim of the state.

\footnotetext{
${ }^{4}$ Insolvency (bankruptcy): Federal law of 26.10.2002 No. 127-FZ, Sz RF, 28.10.2002, No. 43, art. 4190.

${ }_{5}$ Passport of the project of the Federal law No. 165603-3 "On insolvency (bankruptcy)" // ATP "ConsultantPlus".

6 The conclusion of Committee on the property from 14.02.2002 No. 3.9-12.12 "On the draft Federal law No. 165603-3 "On insolvency (bankruptcy)" // ATP "ConsultantPlus".

7 The conclusion of Legal Department of state Duma FS of the Russian Federation dated 18.02.2002 No. 2.2-1/5059 "On the draft Federal law No. 165603-3 "On insolvency (bankruptcy)" and the draft resolution of the State Duma" // ATP "ConsultantPlus".
} 
However, it is important to differ the connecting basis between participants of the tax obligation relation and the concept of a state as an involuntary creditor. State, on the one hand, fulfilling its public function of an assurance of public interest and collection of taxes, but, on the other hand, a status of an involuntary creditor in this situation does not have negative aspect as both parties are deemed to act in bona fide, and legal connection is created with the normal economic activities if the parties. But in the situation of insolvency of debtor the conception has particularly different meaning. Undoubtedly, business activity - it is an risky activity of the parties of business relations, and thus, nobody is secured against the bankruptcy. On the other hand, bankruptcy usually is used as an instrument of evasion of debts coverage, including taxes. Hence, the concept of "involuntary creditor" has a meaning in connection with bad faith debtors, whose aim is to abuse law or cause damages to other creditors. The complex research of particular bankruptcy cases enables to disclose methods of abuse of rights. For example, by the operated creditor indebtedness, or by transfer of assets of a debtor to affiliated entities on legal basis and by voidable contracts, or with a consent of a group of creditors, or by the assignment of affiliated arbitration managers for bankruptcy procedures.

It is evident that the state cannot control these planned situations. Controlled bankruptcy becomes the big agreement for the conception of involuntary creditor, but it is one situation and such arguments cannot be used for the change of legal order of creditors' priorities.

The concept of involuntary creditor can be interpreted differently, by giving the priority to tax claims in the bankruptcy cases or granting tax authorities with particular rights, realization of which will lead to the change of priority order. However, not all situations of realization of involuntary creditor conceptions lead to negative results for private creditor. For example, the conception can be used only in liquidation procedures. The application of it stimulate a debtor and lead to its rehabilitation. The conception is oriented to save the active subject of business activity that gives work places for people. Consequently, there is a positive outcome for the economy. The understanding by all parties of the bankruptcy case of consequences after the beginning of a bankruptcy administration can be an effective factor for taking all existing measures for support of debtor and his rehabilitation. In our opinion, the conception can be an additional state instrument of economic activity regulation. The general commitment to get the proportional coverage overcomes the intention to organize the debtor's liquidation if there is state priority of claims. All mentioned should be interpreted together with state loses as a result of the sanation of debtor and interest of other creditors to rehabilitation of the debtor.

In any event, the beginning of supervision, external management or rehabilitation are connected with prohibition of obligatory payments for creditors' debts and cessation of penalties, interests, forfeit, and contractual penalties. Thus the evaluation of a concept of an involuntary creditor has to be taken into account together with other factors.

Also there is a right of a tax organ to initiate liquidation procedures of a debtor. Authorized organ can act contrary to the position of other creditors in order to get coverage for a debt. There is hardly a decision for such situation, because it is hard to consider the official interest and develop the universal system of balances. In our opinion, the nonapplication conception has more positive features than the determination of all essential circumstances in the process. 


\section{The origins of the formation and consolidation of the conceptual foundations of the fiscal priority of claims in bankruptcy cases}

But the discussion of the state priority can be found in all developed countries. However, there is an absence of full researches on this topic.

In particular countries there was made a big work for the development of bankruptcy legislation (UK, Germany, France, Italy, Spain, Australia, New Zealand, Canada, US, Mexico, China, Brazil, India and some other countries). The legal systems of these countries are based on models of Continental and Anglo-Saxon legal systems, and considering bankruptcy models: from pro-creditors policy (Australia, Germany) to pro-debtors (Mexico and France) (Romero 2000; Serlooten 2000). These countries have been developed their bankruptcy legislation for the last thirty-five years.

All of these countries give some preferences to the state in comparison with private persons in case of debtor's insolvency.

In the UK the priority of the state has been established since Medieval times. This monarch rule was in absolute priority in comparison with other creditors, and takes its roots in Magna Carta, where was stated that "if a debtor of a King dies, the debt of the King

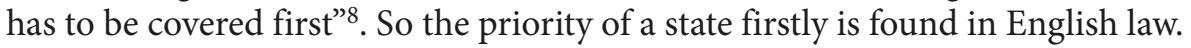

By the common law, a state debt had a priority and, for example, initially in Canada royal power standed for its priority even after the adoption of the first national Canadian law on bankruptcy, claiming that law cannot lessen royal power' .

In the Report of the House of Commons "About the Judicial system" 1977 it is stated, that "tax organ has to be granted with a priority, because it is an involuntary creditor of a debtor. It cannot choose a debtor nor make security measures" 10 .

English law was exported in different countries of the world and saved the concept of state priority even in the absence of monarch. For example, in 1789, during the period, when public revenue of the United States was formed only by customs fees and whiskey tax, one of the first legislative acts of the Congress was granting new federal government right to cover its claims for a debtor before other creditors. 1 Stat. 42 (1789) stated that "in all situation of insolvency ... the debt fir the state has to be covered in the first place". This priority is now codified in 31 U.S.C. $\$ 3713$, but now is not applied in bankruptcy cases.

Now in UK the priority status of bankruptcy cases is partially eliminated as a result of efforts of Sir Kennet Kork. In 1982 under the chairmanship of Sir Kork a special Parliamentary commission presented a report with recommendations concerning the bankruptcy legislation and the practice of its application ${ }^{11}$. In the report it is admitted that the government is an involuntary creditor, however, after arguing with this conception they came to the conclusion, that losses of the state will be less in comparison with private creditors, and that could lead to the bankruptcy of the private creditor as well. It should be agreed, that as much private creditors will get from a debtor, as much tax authorities will

${ }^{8}$ Livre Des Procedures Fiscales, art. L262, L263.

9 Report Of The Review Committee, Insolvency Law And Practice, 1982, Cmnd. 8558, 1409, at 320 (Eng.).

${ }_{10}$ Herbert Smith Reform of the Spanish Insolvency Act http://www.herbertsmithfreehills.com/-/ media/HS/MA-031011-4\%20(3).pdf.

11 Report Of The Commission On The Bankruptcy Laws OfThe United States, H.R. doc. No. 930Ц137, at 216 (1st sess. 1973), reprinted in B Collier on Bankruptcy, app. pt. 4(c), at 484 (15 ${ }^{\text {th }}$ ed. rev. 1999). 
collect from them in the form of taxes. So they descripted an idea about investment for business, that both will return the investments and pay taxes.

The state has other instrument for revenue contributions, for example, it can increase the general tax burden or impose penalties for non-paid or lately-paid taxes. The state, by tax authorities, can impose not only penalties, but other powers for the information collection about a taxpayer, including authorization for internal access, a search, seizure of documents and materials.

In favor of this position there is another argument, that not only the state is an involuntary creditor, but many contractors are limited to choose for prolongation of credit relationship in accordance with rules of business practice, sometimes they are not able to perform effective credit control. There are also other categories of involuntary creditors: creditors for court fees or an injured party of the contract breach or civil injury. With the example of civil injured parties Philip Wood (Wood 1995) argues the concept of involuntary creditor. There is also abusive behavior of the debtor which led to the involuntary status of the creditor.

Another prominent English academic David Lacey wrote, that the majority of state claims have other causes than those of in private sector and gives the example of obligation which is a result of value added tax. He said, that government doesn't have any control for realization of good, although in every situation there is an obligation to pay taxes. State, with putting the burden of counting of the indirect tax on a taxpayer and having significant benefit for it, takes the credit risk concerning the participant of the realization (Lacey 1993). However, in our opinion, in this situation the states does not become the involuntary creditor, because it delegates a number of its functions for tax management for private entities or persons, taking into account that redistribution of powers between public and private persons represents direct intention of the state. Consequently, risk of the insolvency automatically doesn't modify state status to involuntary creditor, but the fact of insolvency changes the nature of relations between parties. Yan F. Fletcher wrote, that information that amounts tax secret is confidential from other creditors, and the absence of this information puts them in unequal position. The seemingly wellbeing of the debtor with the existence of uncollectible tax debts can cause the fully unsecurity of private creditors claims (Fletcher 1997).

In the UK in September 1999 the Chancellor of the Exchequer and the Minister of Trade and Industry James Gordon Brown presented a report on measures for the restoring of the paying ability of a debtor. One of three main elements was a repeated examination of rights and legal remedies of the secured and unsecured creditors in bankruptcy cases involving state participation ${ }^{12}$. After almost 15 years of consistent practice Parliament of the UK almost overcame the concept of the involuntary creditor and equaled state claims in bankruptcy cases with unsecured private creditors. However, till the present day, there are doctrinal disputes of the restoring the priority status of the state in bankruptcy cases (Too 2015).

Colonial England predetermined the legal order and regulations of the majority of issues in other countries, the legislations of which were originally based on the mentioned bankruptcy scheme.

${ }^{12}$ Income Tax Act, 1994, pts. IX, IX, X, and XI (N.Z.). 
The legislation of the UK ${ }^{13}$, Canada ${ }^{14}$, and New Zealand (Wymeersch 2003) ${ }^{15}$ have ambiguous and complicated rules about bankruptcy priorities. Taking onto account common origins, there are many similar legal rules.

In 1970 in the Canadian Parliament was presented a report about bankruptcy legislation arguing with the conception of involuntary creditor ${ }^{16}$.

The question was directly addressed to a legislator: is there any reasons for the prioritized position of the state? The Committee presented revolutionary conclusion: tax claims have to be positioned after the claims of private creditors, because the financial welfare of the state is directly connected with the financial well-being of the private persons.

It is more consistent for the government to support creditors of the insolvent debtor, than stand before them on the priority list. Government must share the burden of unpaid debts with the society and compensate its own losses by supporting economically active and successful business sector.

After 16 years of consistent promotion of the position of the reversal of the priority of state claims, in the Report of Consultative committee for bankruptcy and insolvency of Canada critics appeared again ${ }^{17}$. There is a new argument: persons, who were injured by the debtor, did not have chance to perform due diligence in choosing the debtor, but they cannot enjoy all that rights that state has. By this, there are new disproportions between private creditors and state. Liquidation of the state priority has to cover all federal and local legislation for the granting real benefits to creditors, whose rights are assured, for example, by property deposit.

Jacob S.Zigel wrote, that only in 1992 in Canada the priority of state was reversed (excluding secured by deposit) and refused status of the state as "involuntary creditor" (Ziegel 1998).

The origins of the English bankruptcy legislation and treaty of involuntary creditor traced in Australia, where initially state had priority for the fulfilling of its own claims for the insolvent debtor. The reformer of Australian law was Ron W. Harmer, who in 1988 became the head of the special working group and presented the report for the development of legal bankruptcy rules ${ }^{18}$. The Commission expressed the same idea that tax obligations of the debtor are not significant in comparison with the harm that would be made to the private creditors of debtor.

The reformation position included, that the reverse of the priority to the large extend would stimulate the tax organs to withhold taxed economically rationally, and to change the dependence on unreasonable priority to private creditors. It was supposed that a tax

13 Insolvency Act, 1967 (N.Z.).

14 Bankruptcy Act, No. 33 of 1966 (Austl.); House Comm. On The Judiciary, to accompany H.R. 8200, H.R. rep. No. 95-595, at 190 (1977), reprinted in 1978 U.S.C.C.A.N. 5963, 615.

15 Codigo Fiscal de la Federación, D.O., (December 31, 1981), art. 149; Corporations Law, 1993, pt. 5.4 (Austl.); First Australian Law Reform Commission, Report No. 45, General Insolvency Inquiry 734, at 299 (1988) (Austl.); Fisheries Act, 1983, \$ 107K(3) (N.Z.); New Zealand Law Commission, Study Paper 2, Priority Debts In The Distribution Of Insolvent Estates. 98, at 30 (1999); Radiocommunications Act, 1989, $\$ 183(4)($ N.Z.).

16 Report Of The Commission On The Bankruptcy Laws Of The United States, H.R. doc. No. 93-137, at 216 (1st sess. 1973), reprinted in B Collier on Bankruptcy, app. pt. 4(c), at 484 (15 ${ }^{\text {th }}$ ed. rev. 1999).

17 Insolvenzordnung, v. 5.10.1994 (BGBl. I S.2866). (translated in Charles E Sewart, Isolvency Code, Act Introducing The Insolvency Code (1997)) (F.R.G.). Abgabenordnung (Federal Fiscal Code).

${ }^{18}$ Customs and Excise Act, 1966, pt. IVA (N.Z.). 
department could and had to coordinate its conduct with other creditors. The holding of the old order would mean had creditors were involuntary in a relation with a debtor.

A debtor had to present periodic reports in connection with the payment of the salaries, value added taxes, sales taxes and other fees from the workers' salaries, that tax organs would be promptly informed about the insolvency moment. Government is able without any serious risk for itself let tax debts grow, having a priority in coverage, however, it could seriously harm other creditors' rights. They would not be informed about the growing debts, and finally, would suffer by continuing to work with the taxpayer, if he got to the bankruptcy procedure in future. As a result, the conception of "state- involuntary creditor" produces the reverse result, when private creditor becomes the involuntary creditor with the absence of any guarantees for the coverage.

The Australian legislator made the right decision for the changing of the legislation, from one side, abolished the economically disadvantageous state priority, and from the other side, established another preference, for example, personal subsidiary responsibility of head managers of a debtor for uncovered tax amounts, and also qualified property tax as secured by deposit ${ }^{19}$.

Till 1999 in New Zealand there were rules of tax management, based on the involuntary creditor conception, that enabled the state to avoid bankruptcy procedures. Factually, bankruptcy legislation did not directly limit the rights of tax organs for the application of measures of enforced collection, that were not granted to private creditors. Tax organs could make the enforced collection of the third party property for the coverage of debtor's unpaid taxes. And after the exhaustion of non-court remedies, tax authorities saved their rights to enter court proceedings at any time by including their claim into the list, avoiding preliminary application for unpaid debts.

In October 1999 the Law Committee for the legislation development of New Zealand published a report with recommendations for the limitation of priority of tax claims for insolvency cases $^{20}$.

By this the concept of involuntary creditor, that had existed in the UK and in a number of colonies for many years became inconsistent with the requirement of present society and was reversed.

This position refuses the argument, that the conception of involuntary creditor can make the positive influence for the rehabilitation process of a debtor and counterposes the enlargement of terms for the coverage by private creditors.

The presented academic works made a real influence on the content and establishment of the involuntary creditor concept in positive law of the UK, Canada, Australia and New Zealand, but, unfortunately, it has to be mentioned, that in spite of all measures for the overcoming of private and public claims stratification, there are still particular preferences of the tax claims in all states.

The present countries paid particular status for corporate income tax, after the covering of salary debts. Except Australia, other countries came to the conclusion that personal income tax and social payments from the salaries have to have the priority in bankruptcy cases. British Parliament limits the priority of personal income taxes by time, and Canadian legislator puts personal income taxes between secured and non-secured claims of

19 Bankruptcy Act (January 22, 2003; effective January 1, 2004); Companies Act, 1993 (N.Z.).

${ }^{20}$ McDermott v. United States, 507 U.S. 447, 449 (1993) (quoting United States v. New Britain, 347 U.S. 81, 85 (1954)). 
private creditors. The Law Committee for the legislation development of New Zealand recommended to save the priority for the levy personal income taxes from salary, because it is unfair to collect taxes from employees and also the enlargement of the bankruptcy estate by the property that did not belong to a debtor. Moreover, conservative England saved the priority of excise duties, limited them by the terms of appearance by one year before the bankruptcy case and value added tax by 6 months before bankruptcy case.

Hence, some there are still some features of the conception "state- involuntary creditor" in the legislation of some countries.

South Africa is one of the remarkable examples of past British colony, where conception exists nowadays.

Bankruptcy legislation of South Africa has long history and was changed significant number of times. The earliest legislative act was a law of 1936, applied with several changes by 1973 law $^{21}$. The South African legislation still gives guarantees for tax claims in bankruptcy cases (Swart 1980).

The attempt of South Africa to eliminate tax priorities was unsuccessful. In 1984 South African Law Legislative Commission recommended to save preferences for employees claims and reverse tax priorities ${ }^{22}$. In 1989 the government of South Africa refused these recommendations and held the position of the Ministry Cabinet for the economic issues, that abolishment of preferences could not be supported, because it could lead to unbeneficial consequences for the state, and bankruptcy became the method of "involuntary credit" 23 . Therefore, involuntary status of public creditor overcame principles of equity and proportional redress for creditors.

\section{The Genesis of legal thought on the priority of the state's fiscal interests in case of bankruptcy of the taxpayer}

There is a more unfortunate situation for private creditors in other countries. There were argument in opposition for the conception in the United States, Mexico and France, but they did not find sufficient support. The state priority is balanced with the opportunity to set limits for claimed sums as counter legal remedy. In the US Senate Report, for example, there is a notion, that there are three adversary interests in bankruptcy cases: budget, that could not store up debts for the previous periods; a debtor, whose "new start" could not be limited by old debt before the state; and interest of the tax authorities, that could not spend money for collecting of irrecoverable debt ${ }^{24}$.

In the US reform seem to be partially controversial. Commission for bankruptcy legislation in 1966 recommended the limitation of tax priorities up to 3 years before bankruptcy procedures ${ }^{25}$, but according to 11 U. S. C. $\$ \$ 507,545$ (1994) Congress transformed this recommendation and went feather by establishing the limit of 1 year for tax authori-

${ }^{21}$ Senate Comm. on the Judiciary, to Accompany S. 2266, S. REP. No. 95-989, at 14 (1978), reprinted in 1978 U.S.C.C.A.N. 5787, 5800.

${ }^{22}$ South African Law Commission Working Paper 61, Review Of The Law Of Insolvency: Statutory Provisions That Benefit Creditors (1995).

23 South African Insolvency Act 24 of 1936, applicable to the Companies Act 61 of 1973. (Can.).

${ }^{24}$ Report Of The Study Committee On Bankruptcy And Insolvency Legislation 3.2.075, at 123 (1970)

${ }^{25}$ Report of the Advisory Committee on Bankruptcy and Insolvency 79 (1986) (Can.). 
ties' claims. In the US all special priorities are regulated in one part of a bankruptcy act. Tax claims have to be covered after deposit creditors, salaries payments and coverage of other current spending, but before unsecured credits. Priority is granted regardless of having a tax deposit. If tax organ issued the notice about tax deposit before the bankruptcy, taxes would be paid as a debt before a secured creditor.

In France, these issues are regulated by a law of bankruptcy, by the Civil Code and different chapters of the Tax $\mathrm{Code}^{26}$. In France tax claims must be presented until the bankruptcy procedure in order to have priority to private property (movable) of a debtor. Priority for the immovable property can be granted only in case of registration of mortgage before the bankruptcy procedure. The existence of such priority does not exclude the current expenditures for the case, salaries payment and other personal liabilities (alimonies, injuries).

The changes in French legislation was positively noted by Alan David: "before the law of 1985 taxes and social payments in general form were taking away all business assets and ruining hopes of other creditors to get a compensation, accordingly the rights of privileged creditors were fairly lowered" (Alain 1993).

The French system of bankruptcy was reformed in 1984- $85^{27}$. The aim of legislation changes was not only establishing rules for debts acquittal, but active encouragement of the effective processes of business debts settlement (Weber 2005). The French system is unique for its organs that only operate for bankruptcy cases - Commercial Tribunals under the headship of professional business judges, that are elected by local trade chambers in order to try bankruptcy cases several days a week as judges. Unlike judges, they have practical experience and extraordinary powers. The procedure under the $1895 \mathrm{Law}$ should be led in order to settle the debt or reorganize a business entity.

Rules regulating the priorities and preferences for tax authorities are situated in the General Part of the Tax Code and not in the law of bankruptcy. Among other privileges there can be marked obligatory public payments, connected with movable property. There is not such priority for the immovable property except of there is a registered deposit contract between a taxpayer and a tax authority. With regard that all preferences are exclusions from the general rules they can be interpreted as limitations for other creditors' rights.

However, taking into account all liberal features of bankruptcy procedures, French legislator limited terms for each category of state claims: general direct taxes, for example, private income tax and gross income tax -4 years, value added tax -4 years, registration and stamp duties -2 years, excise duties, taxes on sport events and TV commercials -2 years, claims of custom services of confiscation and fines -3 years. Claims for similar social security and pension payments have a priority like tax ones, but these claims are presented by specialized private organizations.

The Treasury fixes public claims by quarterly application to commercial courts. Moreover, mentioned priority rule of the Treasury exists even in the situation when deposit was registered after the beginning of bankruptcy procedures ${ }^{28}$.

${ }^{26}$ Insolvenzordnung, v. 5.10.1994 (BGBl. I S.2866). (translated in Charles E Sewart, Isolvency Code, Act Introducing The Insolvency Code (1997)) (F.R.G.). Abgabenordnung (Federal Fiscal Code).

27 Insolvenzordnung, v. 5.10.1994 (BGBl. I S.2866). (translated in Charles E Sewart, Isolvency Code, Act Introducing The Insolvency Code (1997)) (F.R.G.). Abgabenordnung (Federal Fiscal Code).

28 Bankruptcy Act and to amend the Income Tax Act, ch. 27, 1992 S.C. 559 (Can.). 
The Treasury has another remedy that other creditors do not have. According to the Law on Tax procedures, The Treasury can notify third parties that debts for this debtor has to be paid to budget immediately ${ }^{29}$. This right was not limited by the 1985 law (Serlooten 2000).

As in many countries, French legislation establishes subsidiary responsibility for the head management of the debtor for uncovered taxes if it is a consequence of voluntary and fictitious bankruptcy, other illegal activities during bankruptcy and other breaches of tax law, that led to the impossibility of tax collection.

The legislation of Mexican United States also, as in many countries, is based on the application of the conception "state- the involuntary creditor".

The earlier existed bankruptcy law established the hierarchy between tax claims in accordance with tax legislation. It was provided that federal laws had priority for other tax claims and private persons. Public claims for social security was equaled with tax claims. The exclusion was claims guaranteed by a deposit, alimonies, salaries payments. However, a deposit has to be publicly registered before the bankruptcy (Day 2000).

A new law on the commercial insolvency came into force on $12.05 .2000^{30}$. The law replaced earlier law on bankruptcy and suspension the payments of $1943^{31}$. As the earlier act, new law regulates questions of business entity insolvency, and the individuals bankruptcy is regulated by state law (Berdeja-Prieto 1994).

With the new law was changed the jurisdiction for cases: they all were shifted to federal courts from state courts (Sánchez-Mejorada 2000). In accordance with new legislation, there is one procedure for all bankruptcy cases, in contrast to earlier procedures of all payments moratorium and liquidation (Rowat, Astigarraga 1999).

In accordance with research of the American Law Institute, a selling of business entity is seemed to be most preferable form of reorganization by Mexican legislation, because it enables to save working places and current entity ${ }^{32}$.

However, mentioned problems from the previous legislation cannot be claimed as decided in the whole amount, because there are a fixed growth of non-court settlement of tax disputes and measures to by-pass new bankruptcy procedures (Rowat 1999).

The earlier bankruptcy law did not regulate the participation of tax organs in bankruptcy cases, but Federal Tax Code had possibilities to levy tax without bankruptcy participation ${ }^{33}$.

Factually, court, trying the case, was obliged to notify the Federal Treasury, that could apply the measures of obligatory tax payments outside of a bankruptcy case with application of all lawful methods of collecting debtor's property and selling it.

According to position of some academics, there are gap in law on bankruptcy that giving possibility of collecting for tax authorities in the situation, if between creditors there is not a reorganizational agreement or on selling a debtor’s entity (Sánchez-Mejorada 2000).

${ }^{29}$ Ley de Quiebras y Suspension de Pagos, D.O. (April 20, 1943) (translated in 1 Mexican Law Library Commercial Codes, Business And Commercial (William D. Signet, ed. 1997)).

30 Legal Department, International Monetary Fund, Orderly \& Effective Insolvency Procedures: Key Issues VII (1999). http://www.imf.org/external/pubs/ft/orderly/index.htm.

${ }^{31}$ Ley de Concursos Mercantiles, D.O. (May 12, 2000).

32 Act 38/2011, of 10 October, reforming the Spanish Insolvency Act 22/2003, of 9 July (Ley 22/2003, de 9 de julio, Concursal) was published in the Spanish Official State Gazette (Boletín Oficial del Estado) last 11 October 2011.

33 Code General Des Impots, art. 1929 ter. 
The new law provides that all tax claims have to be covered after secured claims and current payments, connected with bankruptcy case itself.

The Directors' Council or the sole manager bear a subsidiary responsibility in cases of voluntary evasion of tax payments with taking measures of excluding the debtor from a list, changing of company's address without obligatory notification or of accounting documents were changed or destroyed.

To conclude, the United State, Mexico and France keep priorities in bankruptcy for the wide range of tax claims and social payments. Each of these countries hold the priority of claims for salaries above the claims of other creditors, however, still countries' measures are not alike generally. In Mexico priorities are covered by the Tax Code, employment and insolvency legislation. In the US and France different types of taxes have different time priorities. In the US these priority terms are longer, but it can be explained by complicated procedure of tax debt definition. For example, priority for corporate income tax is almost unlimited, but ad valorem property taxes and custom fees are significantly limited be the period before the bankruptcy. In Mexico all federal taxes have priority and right for the collection is limited by legal period of limitation (Tron 1997).

The conception of involuntary creditor differs in all three countries.

\section{Balance private and public interests in bankruptcy cases}

The different approach in overcoming the conception of involuntary creditor could be found in Federative Republic of Germany, where the primary tax claims had a priority for the private claims. Then all priorities were abolished ${ }^{34}$.

Cristoph G. Paulus stated the new bankruptcy legislation, which came into force by the 1.01.1999 in Germany (Paulus 1998). It provided the direct abolishment of "general system of fiscal preferences" (Jackson, Kronman 1979).

The changes were caused by logical and political causes, but unfortunately, they do not have sufficient empirical basis of economic research (Lopez-Ibor, Artes-Caselles 2003).

One of the draftsmen of Insolvenzordnung Dr. Manfred Baltz said, that Insolvenzordnung was a codification of bankruptcy theories of Prof. Thomas Jackson. It was the first time in German history when legislative power consulted and based its act on the analysis of existing regimes of insolvency and accomplishments of institutional economics (Balz 1996).

Professor Thomas Jackson writes, that for Germany legislation on insolvency should not create any special preferences for collecting tax debts. He writes, that the creation of new rights for bankruptcy cases oppose ideas of collective production. These changes stimulate tax organs to turn to bankruptcy procedures in order to receive benefits. These terms are predictable and contra productive, because they do not decide the fundamental problem, connected with impossibility of cover company's debts (Jackson, Kronman 1979). According to this opinion, priorities for taxes and payments should be granted by the tax and not by the bankruptcy legislation. Consequently, if the tax law does not include any special priorities for before-bankruptcy claims, there should be no such preferences in case itself.

${ }^{34}$ Insolvency and Companies Recover Portuguese Code, effective September 2004 (the 2004 Insolvency Code). 
Douglas Baird agreed with such opinion: necessary priority might be granted by the existing rules of obligations ranging, for example, by tax deposit for a debtor's property (Baird 1992), by using legal constructions, that can be available for private creditors.

Important to mention, that Germany with its revolutionary idea of abolishment of all preferences became the ideal model of bankruptcy legislation, based on the equality of rights of all creditors (Walters 2009). By this example Estonia ${ }^{35}$, Poland, Portugal, Spain and Argentina also limited tax claims for the stimulation of business, on one hand, and for the compensation of losses by other payments of debtor - on the other.

Respective international economic institutes recognized the necessity of equal rights of creditors on bankruptcy cases without regard to the legal nature of their claims. They do not oppose directly to the conception of the involuntary creditor, but International Monetary Fund call governments for the unified approach for tax claims in bankruptcy cases. By postponing the creation of unified rules for everybody, the state mines discipline factor of the effective bankruptcy legislation ${ }^{36}$.

There is a tendency for the reduction of tax priorities in both developed and developing states.

Eleven countries (Hong Kong, India, Indonesia, Japan, Korea, Malaysia, Pakistan, Philippines, Singapore, Thai bay and Thailand), included in the Report of the development of technical assistance in bank activities and reforming insolvency legislation (1999) ${ }^{37}$, saved tax priorities for tax claims in comparison with unsecured creditors.

Countries with transition economies usually have more tax priorities in comparison with developed ones. Effective rules of tax management and execution of law are important for the elimination of involuntary creditor's effect for the state. Hence, if tax legislation is not effective, the abolishing of tax priorities is not the best way of supporting business and balance of interest.

It is important to mention in order to prevent the theory of involuntary creditor in Russia, that according to the principle of equity in Article 1.1 of the Civil Code of the Russian Federation, and also Article 124 of the Civil Code, the state is a member of the civil relations with equal status in comparison with other participants of such relations individuals and entities.

The involuntary status of the state is not objectively justified, as private creditors has less information before the bankruptcy in comparison with state authorities. Consequently, private creditors become the "victim" of the insolvency of a contractor and cannot take measures for the safety of their property rights.

Moreover, tax obligation presupposes obligation of the debtor to pay taxes without regard to any factors, thus debtor becomes involuntary debtor.

There is particular approach to the abolishing of the priority for public claims for the common benefit of market participants, that use debtor's money to develop their business. This kind of investments will lead to the greater revenue by later paid taxes. In the same

35 Asia-Pacific Restructuring and Insolvency Guide 2003/2004. Accessed September 29, 2018. http:// www.asianrestructuring.com.

${ }^{36}$ Law No. 84-148 of March 1, 1984, effective March 1, 1985; and Law No.85-89, subject to Decree Nos. 85-1388 and 85-1389 of December 27, 1985. Amendments were enacted in 1994. Law No. 94-475 of June 10, 1994.

37 American Law Institute, Transnational Insolvency Project, International Statement Of Mexican Bankruptcy Law 97 (Tentative Draft 1998); Asian Development Bank, Report on the Results of The Technical Assistance. Accessed September 29, 2018. http://www.insolvencyasia.com. 
way should be treated positive preventive effect of equal status of public and private creditors, that limits the future bankruptcy of crediting entities. In the reverse situation the realization of the conception of involuntary creditor can lead to the worsen the economic situation in the country where one bankruptcy can be a factor of bankruptcies of its creditors - house of cards effect.

Admitting the insufficient security of public right in bankruptcy cases, legislator should take measures to reach one aim - the establishment of equal rights of public and private creditors. Current Insolvency (Bankruptcy) Act does not regulate directly the status of the state in the situation of tax deposit security. In the present moment, literally interpreting a rule of law, deposit creditor can be only a private person/entity. In our opinion, changes of the deposit status of the debtor with the note of possible security by the debtor's property for the state tax claims is a consistent and up-to-date necessity. The deposit status of the authorized organ comes directly from the Article 73 of the Tax Code. Hence, bypassing the conception of involuntary creditor, there is a possibility to provide equity of public and private creditors, that could enlarge tax collections from insolvent taxpayers with no application of list of priorities.

In connection with presented academic positions, practice of the reforming of foreign legislation it is possible to conclude, that the realization of the conception of the involuntary creditor in Russian legislation could have harmful consequences for economics and law, undermining the basis of civil relations.

\section{6. "Unequal equality": the absence in the Russian legislation symmetric rules for participation in bankruptcy cases for the authority and bankruptcy creditor}

Tax authorities represent public interest in bankruptcy cases on the basis of the Federal law (26.10.2002 No. 127-FZ) "Insolvency (Bankruptcy) Act"38 and the Russian Government Regulation 29.05.2004 No. 257 "Of the security of interest of the Russian Federation as a creditor in bankruptcy cases and bankruptcy procedures" 39 and the Regulation of the Ministry of Economic Development and Trade 19.10.2007 No. 351 "About the proceeding of selection of the arbitration manager by the authorized organ" and the Regulation of the Ministry of Economic Development and Trade 03.08.2004 No. 219 "About the procedure of the voting in bankruptcy cases and bankruptcy procedures for the participation in creditors meetings" 40 .

38 Federal law of 26.10.2002 No. 127-FZ (as amended on 03.07.2016) “On insolvency (bankruptcy)" // SZ the Russian Federation, 28.10.2002, No. 43, art. 4190.

39 The decree of the RF Government dated 29.05.2004 No. 257 "About maintenance of interests of the Russian Federation as the creditor in business about bankruptcy and in procedures, applied in business about bankruptcy" // WP, No. 113, 01.06.2004.

40 The order of Ministry of economic from 19.10.2007 No. 351 "On approval of Order of selection authority to represent in Affairs about bankruptcy and in procedures of bankruptcy of the requirement about payment of obligatory payments and requirements of the Russian Federation for monetary obligations, self-regulatory organizations of arbitration managers when submitting to the arbitration court statement declaring the debtor bankrupt and introduction of amendments to Order of Ministry of economic development of Russia from August 3, 2004 No. 219 "On the Procedure of voting of the authorised body in Affairs about bankruptcy and in bankruptcy procedures at participation in meetings of creditors" // WP, No. 294, 29.12.2007. 
But neither Insolvency (Bankruptcy) Act, nor any of regulations do not mention the situation where state organ could have assurance of claims in the form of a deposit.

S. A. Yadrichinskiy was first academic who started to speak about the possibility of deposit status of an authorized organ in bankruptcy cases (Shershenevich 1890). Till the present moment there was no example in courts practice of such assurance of claims for the part of obligatory payments. But it does not mean the impossibility of such assurance. Due to the Ruling of the Arbitration Court of Lipetskaya oblast 12.12.2012 No. A36$3505 / 2012^{41}$, claims of the Federal Fiscal Service (based on the state guarantee) are included into list of creditors' claims as assured by property of a debtor.

The establishment of the deposit as a method of assurance of tax payment is in accordance with the specific connection, which has the additional character to the main tax relation - subordinate relation. An assuring legal relation has a significant influence for the deposit relation (Imykshenova 2005). As T. A. Savelieva says, the coordination of such obligations does not lead to the full dependency, deposit has the relative independence (Savel'eva 1998, 12-13).

There is the definition of tax deposit in the Article 73.3 of the Tax Code of the Russian Federation: "In the situation of the absence of fulfillment of obligations for the payment of tax or other fees by a taxpayer, a tax organ can fulfill this obligation by the value of deposited property in accordance with the civil laws of the Russian Federation". The independence of the institute of a tax deposit can be proved by the legally established tax liability and sanction in the form of fine (Article 125 Tax Code).

However, the legislator does not mention the term "priority right" of claims compared to other creditors. Although the creation of the institute of tax deposit by itself gives tax organs insurance in the future covering of tax payments obligations by the deposited property of a debtor or another person priory to other creditors. In other case, there could be nonsense situation, because Article 47 Tax Code generally establishes the right of tax organs to withhold a tax by a taxpayer property without any deposit in case of nonpayment.

It is possible to agree with E. Y Latypova, who says that the nature of the deposit is a priority right tax organs comparing to other creditors to receive coverage by debtor's property (Latypova 2004, 75-79).

This rule of the priority rights of tax organs has the specific value in the situation of bankruptcy of a taxpayer, for example, in a procedure proportionate coverage of debts. In case of the insolvency and decrease of the property during the deferral time coercive recovery measures might be ineffective. In case of the bankruptcy of such taxpayer, due to the Article 134.4 of the Insolvency (Bankruptcy) Act, tax organs are included in the third stage of priority and in the majority of cases in the absence of a deposit debts are just being written off because of insufficient amount debtor's property.

The existence of a deposit gives the tax organ status of the secured creditor. At the same time the beginning of the bankruptcy proceedings does not automatically lead to transformation of the claims of a secured creditor to the unsecured financial claim - the security holder still has the right to cover his claims from the value of the deposit, but now by the bankruptcy rules.

41 The Arbitration court of Lipetsk region dated 12.12.2012 on case \# A36-3505/2012 // The Document was not published. ATP ConsultantPlus. 2016. 
The priority of the secured creditor in comparison with other creditors means that he has a right for at least $70 \%$ of the value of the realized deposit. However, this sum cannot overcome the sum of the main obligation together with interest (Art. 138.1 Insolvency (Bankruptcy) Act, para 15 of the Resolution of the Presidium of the Supreme Arbitration Court 23.07.2009 No. 58 "About issues considering fulfillment of claims of a security holder in cases of bankruptcy of a depositor" ${ }^{\text {" }}$. The institute of a tax deposit plays a role of a guarantee for a taxpayer obligation.

In the first redaction of the Tax Code sphere of the secured deposit was limited only by situations of changing period for payments of taxes. However, in 2010 the wording of the Article 73.1 was changed and now tax deposit can be applied in all other situations of tax obligations described by the Tax Code ${ }^{43}$.

Since 2013 there is a rule in the Article 77.12.2 of the Tax Code ${ }^{44}$, that under a request of an entity - taxpayer seizure of property can be changed for the deposit of property. The decision of seizure is being abolished (Article 77.13 of the Tax Code).

Consequently, apart from the powers granted by the Insolvency (Bankruptcy) Act and the Russian Government Regulation 29.05.2004 No. 257 "Of the security of interest of the Russian Federation as a creditor in bankruptcy cases and bankruptcy procedures", a tax organ acquires additional powers for the determination of the procedure, requirements and period of selling of a deposited property, right to make motions before the Court for the minimal selling price of the property and right to hold the object of deposit on its own balance in case of failure to fulfill the obligations by a taxpayer.

However, neither the Insolvency (Bankruptcy) Act, nor the Tax Code do not mention tax deposit in cases of legal entities bankruptcies and do not supposed to grant the tax organ the same rights as a deposit creditor with private claims has.

Furthermore, the only fact of initiation of the procedure by a debtor can be a basic for the obligatory preliminary conclusion of a deposit contract with a debtor.

The evident insufficiency of legal regulation for this aspect requires improvements of legislation. However, it seems to be logic to refer to the international practice at the first step.

Priorities, that are given for the tax claims in other countries, usually become evident because of the special regime of debts coverage. The particular requirements for the priority widely vary in other countries and usually depend on a type of a tax and a tax period.

Even if national bankruptcy legislation does not give preferences for tax claims, these preferences can be regulated by the general taxation legislation. For example, if the taxation legislation has provisions of deposit of the property for the tax payment, taxation

42 The resolution of the Plenum of the Russian Federation from 23.07.2009 No. 58 "On certain issues related to satisfaction of demands of mortgagee when the mortgagor bankruptcy" // Bulletin of the RF, No. 9, September, 2009.

43 Federal law of 27.07.2010 No. 229-FZ (ed. 03.07.2016) "On amendments to part one and part two of the Tax code of the Russian Federation and some other legislative acts of the Russian Federation and on annulment of certain legislative acts (provisions of legislative acts) of the Russian Federation in connection with the settlement of arrears in the payment of taxes, fees, penalties and fines and some other issues of tax administration," / / WP, No. 169, 02.08.2010.

44 The Federal law from 23.07.2013 n 248-FZ (ed. 02.04.2014) "On amendments to parts one and two of the Tax code of the Russian Federation and some other legislative acts of the Russian Federation and on invalidating certain provisions of legislative acts of the Russian Federation" // RG, No. 163, 26.07.2013. 
claims in bankruptcy cases will have priority in comparison with other non-secured creditors.

For example, state and local taxes in Canada usually are in the same stage of priorities with non-secured creditors in bankruptcy cases. However, there are some exclusions, among them the possibility to register deposit claims of the state before the bankruptcy procedure and to equate rights with claims of other deposit creditors (Ziegel 1996; Simpson 1999).

Considering the US legislation, there is a priority defense of federal and regional taxes, secured by deposits, by the fulfillment of the formalized procedure, which the obligatory requirement is a court application. In other case the state losses its right for the defense for the deposit part, especially with a bona fide acquirer of property (In re Lyons 1994). Tax deposit usually has to be registered, for example, by the Virginia state legislation, the text deposit has to be registered in an office of circuit court ${ }^{45}$. Priority of the crossing tax deposits usually identified by a rule "the first by time- the first by law" 46 . By the common law, federal tax deposits are considered as prioritized in comparison with other claims (King 2000). Secured tax claims have to be covered at the full amount with interest for a date of confirmation of a restructuring debt plan ${ }^{47}$.

In 1994 in the Federal Republic of Germany there was enacted Law of insolvency (InsO), that came into force in 1999 (Paulus 1998). Before that there was not effective procedure for the tax claims. Mostly probably, that German legislators took into account U.S. experience as a model for problem solving. Generally acknowledged, that there was a significant influence of Prof. Thomas Jackson (Kamlah 1996). One of the draftsmen of Insolvenzordnung Dr. Manfred Baltz said, that Insolvenzordnung was a codification of bankruptcy theories of Prof. Thomas Jackson. It was the first time in German history when legislative power consulted and based its act on the analysis of existing regimes of insolvency and accomplishments of institutional economics (Wymeersch 2003). Tax organs may register an obligatory deposit of the immovable property omitting court stage in bankruptcy proceedings.

The French system of bankruptcy was changed in the period of $1984-1985^{48}$. The aim of the legislative changes was not only establishment of the set-off debts rules, but also active encouragement of the effective settlements considering business entities obligations (Koral, Sordino 1996). New rules included tax deposit, which had to be obligatorily registered before as well as after beginning of bankruptcy proceedings ${ }^{49}$. All priorities, as exceptions from the equality rule, were being criticized (Lacey 1993).

In Spain, the Insolvency Act was adopted in 2003, came into force in 2004 and now is in 2011 redaction ${ }^{50}$. Before the adoption of the Act tax claims were in priority to the claims of private creditors ${ }^{51}$. After the abolishing of the priority rule government decided to make tax deposits as ordinary practice in liquidation procedures.

\footnotetext{
45 United States v. Haas (In re Haas), 162 F.3d 1087.

46 Magna Carta (Confirmed version), 9 Henr. III, 1225, C.18.

47 South African Law Commission, Report on Amendments to South Africa.s Insolvency Laws (1984) [ISBN 0621090840$].$

48 Insolvenzordnung, v. 5.10.1994 (BGBl. I S.2866) (translated in Charles E Sewart, Isolvency Code, Act Introducing The Insolvency Code (1997)) (F.R.G.). Abgabenordnung (Federal Fiscal Code).

49 Bankruptcy Act and to amend the Income Tax Act, ch. 27, 1992 S.C. 559 (Can.).

50 A Review Of Company Rescue And Business Reconstruction Mechanism $\$ 1(\mathrm{~b})$.

${ }^{51}$ Goods and Services Tax Act, 1985, pt. III (N.Z.).
} 
Since 2004 there is bankruptcy legislation in Portugal ${ }^{52}$. Before the adoption of a Code there was absolute priority of tax claims before private ones. One of the features of Portuguese regulations is a priority of tax claims that were created during 12 months before bankruptcy. In regarding with bankruptcy deposit, it has to be created at least 2 months before the bankruptcy.

To conclude, in developed states and in countries with a long history of bankruptcy regulations, on one hand, there are measures against unreasonable public dominancy in bankruptcy cases, and on the other hand, there are institutes being created to secure public claims by the analogy with private claims. During the fair equation of public and private interests public claims should not be less secured than private ones. For this reason, prospective application of the institute of tax deposit for the tax claims seems to be reasonable and logic step of the legislator in Russia.

The juridical technique of the Insolvency (Bankruptcy) Act are based on the delimitation of rights and obligations of bankruptcy creditors and authorized organ, and all rules considering deposit of a debtor and deposit status of a creditor are formulated the way that due to the interpretation deposit can be applied only in private claims situations.

What rights and obligations should organ have with the status of deposit creditor? Following the common logic of the Law, in this situation an authorized organ has several restrictions, for example, loose its right to vote on creditors meetings (except first meeting and those where there is an agenda of the first meeting, and also in the process of bankruptcy supervision; during financial rehabilitation and external management in case of refusal of the deposit realization or the court's refusal for the realization of the deposit; for the question of choosing an arbitration manager or self-regulatory organization, from where an arbitration manager are being appointed; for the question of applying to the arbitration court with the motion of dismissal of the arbitration manager; for the question of applying to the arbitration court with motion of the termination of the proceedings and shifting to the external management; during the restructuring of debts of a person; during the realization of property of a person.

No doubts that organ, which rights are secured with a deposit does not lose its right to participate in the meetings with the right to speak on the questions of agenda.

Authorized organ for the obligations, secured by a debtor's deposit, during the financial rehabilitation and external management saves the right to seize the deposited property if it does not lead to the impossibility to recover the financial solvency of the debtor or there is a risk that in a result of realization property would be damaged, destroyed or its price would be lower.

The realization of deposited object, in accordance with Insolvency Act, is carried by an organizer of the auction. By the general rule of the Article 18.1 Insolvency Act, in cases of a twice failed auction bankruptcy manager for the obligations, secured by the deposit, has a right to take the object of an auction with the estimation not lower than $10 \%$ lower from the initial price on the second auction. Determining the equal rights for the authorized organ in case of deposit property, it is necessary to create a rule that authorized organ can hold the deposited auction in case of failed auction.

Proposition goes beyond the financial fulfillment of tax obligations. According to Article 8.1 of the Tax Code, a tax is an obligatory, individually non-repayable payment,

52 Insolvency Act, 1986, c. 45 (Eng.). 
withholding from organizations and individuals in the form of a transfer of monetary funds they have on the right of ownership, economic or operational control for the aim of financial maintenance of a state and municipalities. Tax obligation - a special property (monetary) obligation, the object of which is money. There is no difference whether money is on cash or non-cash form (on accounts of the credit organizations) (Vinnitskii 2015, 143-144). Therefore, the fulfillment of a tax obligation by other types of property requires another regulation of Article 47 the Act on Insolvency and Federal Law on the Enforcement proceedings ${ }^{53}$. In case of insufficiency of monetary funds on the account of a debtor, a tax organ makes a decision of coverage of the obligation by means of other types of property of the debtor and sends request to the Federal Enforcement Service.

Article 73 of the Tax Code does not send to the Article 47, but directly states that a tax organ covers tax obligations of the taxpayer by the value of deposited property in accordance with civil legislation of the Russian Federation (Articles 249-350.2 of the Russian Civil Code ${ }^{54}$ ). In the bankruptcy situation, the Insolvency Act has the leading role of debtor property realization regulation. Let us analyze the existing rules as if they already regulate the legal status of the authorized organ with deposit.

In accordance with Article 138.4.1 of the Insolvency Act, in the situation of the twice failed auction the authorized organ which manages the secures by deposit obligation has a right to hold the object of the deposit with a value estimation lower $10 \%$ than initial price for the second auction. The authorized organ for the obligations, secured by the deposit, in case of holding an object of the deposit must transfer money funds in the amount that is in excess of the size of the obligation, but not less than $20 \%$ of the realization price, for the special bank account.

Moreover, authorized organ for the obligatory payments, secured by the deposit, in accordance with Article 138.4.2 of the Insolvency Act, has a right to hold the object of the deposit in the way of auction for the realization of the debtor's property by a public proposal on each stage of lowering a price. In case of the exceed price, organ must transfer money to the special account but not less than $20 \%$ of the buying price.

Earlier in the academic works there was similar idea of possibility of holding the object of the deposit by the government but considering special regime of mortgage (the Federal Law on Mortgage ${ }^{55}$ ) (Verstova 2008, 202-203).

Oppositely, Yadrikhinskiy wrote that the Tax Code of the Russian Federation does not give the opportunity to tax organs to hold objects of deposit for the coverage of tax obligations. The payment could be only in monetary form, by the sense of the Article 8 . According to the Articles 47.6 and 48.6 of the Tax Code, a tax obligation is deemed to be fulfilled from the moment of factual receipt of monetary funds from bankruptcy property realization by the public entity (Iadrikhinskii 2015).

We think, that the Insolvency Act can become an exception in the general rule of monetary form of tax coverage. This outcome does not transform the rule, because system

${ }^{53}$ Federal law of 02.10.2007 No. 229-FZ (ed. from 03.07.2016) "On enforcement proceedings" // RG, n 223, 06.10.2007.

54 The civil code of the Russian Federation (part one) from 30.11.1994 No. 51-FZ (as amended on 03.07.2016) (Rev. and EXT., joined. in force on 01.08.2016) // SZ the Russian Federation, 05.12.1994, No. 32, article 3301 .

${ }^{55}$ Federal law as of 16.07.1998 No. 102-FZ "On mortgage (pledge of real estate)" // WP, No. 137, 22.07.1998. 
analysis of existent articles 73 of the Tax Code and 349-350.2 of the Civil Code shows the possibility of such application.

The covered international practice of the agreements on the deposit of taxpayers' property present the possibility of creation of the institute of preliminary deposit for bankruptcy cases. The conclusion of a deposit contract in these situation is in accordance with interests of controlling the taxpayer persons or entities, because it gives them a security from a subsidiary responsibility for debts as a result of abusive behavior.

In conclusion, it is necessary to mention that legal regulation of a tax deposit in bankruptcy cases of entities by the Russian legislation needs development and improvements, however, in legislation there is already certain necessary basis for such legal institute.

\section{Filling gaps in Russian law and harmonization of cross-border insolvency issues in BRICS countries}

Bankruptcy is an instrument for the strengthening of the economic stability in a society on the basis of legal methods of acquittal of bad debts (fresh start). It is not simply a liquidation of the organization with uncollected debts. This procedure cannot be deemed as negative. Oppositely, there can be found clear and effective mechanisms of reliable protection for the interests of private and public creditors in the way of asset reallocation in accordance with demands on the market. Large economic activity, even in the worldwide perspective, cannot be insured of bankruptcy.

In the present time, a term of "Cross-Border Insolvency» has its official determination in the Resolution of the UN General Assembly - UNCITRAL Model Law on CrossBorder Insolvency $(1997)^{56}$.

BRICS countries are involved in the process of cross-border bankruptcies, however, it is known that Russia does not take part in these relations because of the absence of normative regulations in this sphere. After the analyzing of the Russian legislation it is possible to confirm the absence of the systematic regulations in this sphere. In the Federal law "Insolvency (Bankruptcy) Act" there is a notion of the term "cross-border insolvency". Generally, there is a principle of equality between foreign and national creditors in cases of insolvency (Art. 1.5 "Insolvency (Bankruptcy) Act"). Like in many countries, Russian law confirms the prevailing character on international treaties over the national law. Moreover, due to the principle on reciprocity, decisions of foreign courts are recognized on the territory of Russia.

The noted regulations cannot be claimed as sufficient, because the interpretation of the term cross-border insolvency is possible only in one direction: the relation to a foreign country only through creditors or his property. The circumstances of opposite situations with foreign companies - debtors are still not covered (Mokhova 2009, 27).

Civil Code does not regulate questions of cross-border insolvency. Academics are discussing the issues if the absence of a special normative legal act for the insolvency with foreign participation (Anufrieva 2001; Goncharov 2010; Erpyleva 2010; Letin 2003, 80-

${ }^{56}$ Doklad Komissii OON po pravu mezhdunarodnoy torgovli o rabote ee tridtsatoy sessii 12-30 maya 1997 g. [Report of United Nations Commission on International Trade Law (UNCITRAL) Model Law on Cross-Border Insolvency (1997)] // General'naya Assambleya. Ofitsial'nye otchety. Pyat'desyat vtoraya sessiya. Resolution adopted by the General Assembly. Fifty-second session. New-York, 1997. P. 71-81. (www. uncitral. org). 
81; Mokhova 2009, 10-54; Mokhova 2014, 48-66; Mokhova 2013; Mokhova 2014, 62-73; Mokhova 2012, 111-127; Sobina 2012, 195-205; Trushnikov 2006).

International practice of bankruptcies regulations where creditors and debtors were from different countries has been an issue for the academic discussions (Gerner-Beuerle, Schillig 2009; Mucciarelli 2011; Mucciarelli 2013; Leibfritz 2009) and foreign regulation for a long time.

There are many history examples for improvements in domestic law as well as methods of international settlement in cases of insolvency with foreign participation:

Firstly, there are multilateral international treaties:

European convention of transboundary insolvency (1960) - suggested to make a procedure only on the territory of one of the contracting states. This convention is not applicable nowadays, however, is of a doctrinal interest.

European Convention on Certain International Aspects of Bankruptcy (1990). Convention is signed and applied in the situations of parallel proceedings in contracting states.

Convention of the European Union on Insolvency Proceedings (1995) gives regulations in the liquidation point of view and operates with methods of abovementioned conventions.

UNCITRAL Model Law on Cross-Border Insolvency (1997). This international act recommends enaction of a national law, which would regulate informational exchange and primarily oriented for the one-country procedure.

EU Regulation on Insolvency proceedings (2000). This regulation provides the main place of the proceedings in a place of main interest of debtor and the possibility of secondary procedures in contracting states.

In the present article, only recommendations of the UNCITRAL Model Law on Cross-Border Insolvency can be applied as BRICS countries are members of the UN.

Other international regulations can be applied, for example, Bustamante Code (IX Part), rules of OHADA Uniform Act on Bankruptcy Proceedings ${ }^{57}$, Montevideo treaties ${ }^{58}$ of the first and second South-American congresses on private international law 1889 and 1939-1940 respectively.

Secondly, there are bilateral treaties on bankruptcy:

France - Switzerland Treaty (1798);

Convention between Swiss cantons and Württemberg (1826);

France - Switzerland Treaty (1869);

Belgium - France Convention (1899);

Belgium - Austria Convention (1969);

Belgium - the Netherlands Convention (1925);

57 Unifitsirovannyy akt Organizatsii po garmonizatsii kommercheskogo prava stran Afriki "Ob organizatsii kollektivnykh protsedur likvidatsii" [The uniform act of the Organization for the harmonization of commercial law of the countries of Africa "About the organization of collective procedures of elimination"] 1998.

58 Dogovor o mezhdunarodnom kommercheskom prave [Treaty on international commercial law] 1889. Dogovor po voprosam mezhdunarodnogo kommercheskogo prava [The Treaty on International commercial Law] 1940. Dogovor o mezhdunarodnom protsessual'nom prave [Treaty on International Procedural Law] 1940. Gavanskaya konventsiya po voprosam mezhdunarodnogo chastnogo prava, prinyataya 20 fevralya 1928 na Shestoy panamerikanskoy konferentsii, prokhodivshey v g. Gavane (o. Kuba) [Havana Convention on private international law adopted on 20 February 1928 at the Sixth pan-American conference held in Havana]. 
Germany - Austria Treaty (1979);

France-Austria Convention (1979);

France-Italy Convention (1930);

Italy-Austria Convention (1977);

The Kingdom of Netherlands and Federal Republic of Germany Convention (1962);

The United Kingdom and the Kingdom of Belgium Convention (1934).

The abovementioned bilateral treaties on the issues of bankruptcy confirmed principles of universalization and reciprocal recognition of foreign courts decisions, jurisdiction of domicile or the main place of business, competences of bankruptcy managers if it did not contradict the public order (Sobina 2012, 180-200).

The bilateral model is not a universal and can be applied only for two countries, that do not preclude problems in the situation of bankruptcies on the territories of three or more countries even if they have bilateral treaties. For this reason, bilateral treaties have to be replaced by the EU Regulation No. 1346/2000 (Article 44 of the Regulation).

Exterritorial bankruptcies are also relevant for BRICS countries. In China, the institute of bankruptcy of private entities has been applied only since 2007. Earlier there was no term of public claims because the law before regulated only bankruptcy of governmental entities and the main aim was the fulfillment of workers' rights. On April 2015 Baoding Tianwei Company, the subsidiary of China South Industries Group, informed about its default and failure to cover its obligation of $\$ 13,8$ million $^{59}$. Another large developer Kaisa Group also informed about its default ${ }^{60}$. In 2013 a famous Brazilian oil company OGX applied for its bankruptcy with the debt of $\$ 5,11$ billion $^{61}$. Its bankruptcy was the largest among Latin America countries. Also at the end of 2014 around 30 Brazilian companies producers of sugar and ethanol applied for the bankruptcy.

Russia meets problems of bankruptcy primarily when cases cannot be decided by foreign proceedings and related to Russian companies, for example, Resolution of the Presidium of the Supreme Arbitration Court No. 10508/13, 12.11.201362; Resolution of the Presidium of the Supreme Arbitration Court No. 6417/11, 04.10.201163; Ruling of the Supreme Arbitration Court No. 11934/04, 23.06.200864; Ruling of the Supreme Arbitration Court No. 14334/07, 11.03.200865; Ruling of the Supreme Arbitration Court

59 Informatsionnoe periodicheskoe izdanie, 2015. Accessed November 24, 2017. http://www.bloomberg.com/news/articles/2015-04-21/china-sees-first-bond-default-by-state-firm-with-baoding-tianwei.

${ }^{60}$ Informatsionnoe periodicheskoe izdanie, 2015. Accessed November 24, 2017. http://www.bloomberg.com/news/articles/2015-04-20/kaisa-defaults-after-china-developer-says-can-t-pay-dollar-debts.

${ }^{61}$ Informatsionnoe periodicheskoe izdanie "Vedomosti", 2013. Accessed November 24, 2017. http:// www.vedomosti.ru/business/articles/2013/10/31/brazilskaya-neftyanaya-kompaniya-ogx-obyavila-obankrotstve.

62 Decree of the Presidium of Russia from 12.11.2013 N 10508/13 on business N A40-108528/12-501134 // The Bulletin YOU the Russian Federation, 2014, No. 4.

${ }^{63}$ Decree of the Presidium of Russia from 04.10.2011 N 6417/11 on business N A40-26764/10-10199B, A40-27719/10-101-106Б // The Bulletin YOU the Russian Federation, 2012, No. 2.

${ }^{64}$ Definition of the SAC dated 23.06.2008 N 11934/04 in the case N A56-7455/2000 // The Document was not published. ATP "Consultant", 2017.

${ }^{65}$ Definition of the SAC dated 11.03.2008 No. 14334/07 in the case No. A56-14945/2004 // The Document was not published. ATP "Consultant", 2017. 
No. VAS-6393/09, 17.07.200966; Resolution of the Federal Arbitration Court of VolgoVytskiy region No. A79-3955/2009, 11.03.2011 ${ }^{67}$.

Mentioned decisions are just a few examples of a huge international practice of transboundary bankruptcy cases.

The enactment of the special conflict of law rule in domestic and international law considering the application of rules for the bankruptcy cases with foreign element would be an important milestone for the legal technics and normative regulations of BRICS countries. For example, a rule of applicable law of a country where proceedings were started (lex fori concursus).

The BRICS framework can be a «fresh start» of a development of normative base of a cross-border insolvency and its prevention.

The situation of insufficient regulation for the cross-border insolvency can be decided by international practice.

At the same time, it is impossible to solve issues connected with taxation by a simple adoption of foreign rules, because none of the existing treaties regulate these questions. BRICS cooperation opens new ways of economic activity and international banking, and might become the basis of a development of the institute of state participation in bankruptcy cases.

There are following main tax issues in bankruptcy cases with foreign participation.

1. Formulation of the unified criteria for the reciprocal recognition of public claim in contracting states. Firstly, essential criteria can be formalized in an international treaty. Secondly, there could be the unilateral recognition of one state of public claims of another state on the national law level. For example, Art. 5 of the Bankruptcy Law ${ }^{68}$ in China states that if the court of the foreign country issued legal ruling or resolution or the bankruptcy case and if this decision affects Chinese property of the debtor and has the demand to recognize this ruling for the people's court, the court in accordance with international conventions, where China participates, or in accordance of reciprocity principle, evaluates and issues a ruling of recognition and implementation of such document if it does not contradict the basic principles of legislation, state security, sovereignty, public interests of China, legal rights and interests of Chinese creditors. However, the mentioned norm does not establish unified criteria for public claims, but just basically agrees with their existence and possible value for BRICS.

2. The unification of a public claim and an obligatory payment institutes.

The official definition of the obligatory payment is contained in the Article 2 of the Federal law (26.10.2002 No. 127-FZ) "Insolvency (Bankruptcy) Act". Obligatory payments are taxes, fees and other obligatory contributions, which are paid for a budget of a cor-

${ }^{66}$ Definition SAC the Russian Federation from 17.07.2009 No. VAS-6393/09 on business No. A402905/08-62-3 // the Document was not published. ATP "Consultant", 2017.

67 The regulation of FAS Volga-Vyatka district on case No. A79-3955/2009 from 11.03.2011 // The Document was not published. ATP “Consultant”, 2017.

68 Zakon Kitayskoy Narodnoy Respubliki o bankrotstve predpriyatiy, prinyat na 23-m zasedanii Postoyannogo komiteta Vsekitayskogo sobraniya narodnykh predstaviteley 10-go sozyva 27 avgusta 2006 g. [The Law of the People's Republic of China on Enterprise Bankruptcy, adopted at the 23rd Meeting of the Standing Committee of Chinese Meeting of National Representatives of the 10th Convocation on August 27, 2006] // (KNR) Byulleten' Postoyannogo komiteta VSNP za 2006 god. Accessed November 24, 2017. http:// www.china.org.cn/china/2011-02/11/content_21898381.htm. 
responding level of budget system of the Russian Federation and (or) governmental extra budget funds, also administrative punishment fines and criminal law fines. The present definition cannot be deemed as sufficient and covering all types of obligatory payments.

The Supreme Arbitration Court in its Resolution of the Plenum of the Supreme Arbitration Court 23.07.2009 No. 59 "About aspects of the application of the Federal law of "Enforcement proceedings" in cases of bankruptcy" 69 gave the widen definition in which enforcement payment is a kind of an obligatory payment.

There are also legal opinions of the Russian Constitutional Court in its Ruling 10.12.2002 No. $284-\mathrm{O}^{70}$, in which the Court evaluated rules that a payment for the negative influence for the environment is an obligatory public payment (in financial and legal relations). They have individual and compensative character and by their nature are the fiscal fee. The Court ruled that these payments are in the scope of obligatory payments category within the Article 2 "Insolvency (Bankruptcy) Act".

Insolvency (Bankruptcy) Act does not directly name as obligatory payments customs fees, which are being withhold as a result of state border crossing of goods (Customs Code of the Customs Union).

Legislation acts of the bankruptcy other BRICS countries do not determine the category of "obligatory payments", but have blanket rules referring to other acts of tax and fees legislation. Consequently, there is a possibility of conflicts of interpretation and determination of public claims.

3. Granting the authorized governmental organs of foreign countries, the same rights as for domestic organs, or recognition foreign governmental organ as a representative of state-creditor. Problem could be solved by the recognition of a state as a fully legitimate creditor. The equation of foreign governmental organ and domestic organ does not seem to be correct, as rights of this organ are formulated not only within the framework of bankruptcy legislation but other types of administrative legislation. Status of the state organ is a result of its competence but not a consequence of direct financial connection with a debtor. Also, the question of sovereignty of states remains to be problematic.

4. The elimination of collisions of a priority for debt coverage in tax obligations. For example, there could be the comparison of legislations of China, Brazil and Russia.

Article 113 Law of Bankruptcy of China says that after the priority coverage of expenses for the bankruptcy and general obligations property of a bankrupt is being spend for the debts coverage as follows:

1) Debts for salaries, medical benefits, compensations for incapacity for work and invalidity, survivor pensions, basic pensions and medical insurance for workers and other compensations in accordance with law;

69 The resolution of the Plenum of the Russian Federation from 23.07.2009 No. 59 "On some issues of practice of application of the Federal law "On enforcement proceedings" // Bulletin of the RF, No. 9, September, 2009.

70 The Constitutional Court of the Russian Federation of 10.12.2002 No. 284-On "At the request of the Government of the Russian Federation about check of constitutionality of Decree of the Government of the Russian Federation "On approval of the procedure for determining payment and its limiting sizes for pollution of surrounding environment, placement of waste, and other types of harmful effects" and article 7 of the Federal law "About introduction in action of the Tax code of the Russian Federation" // RG, No. 241, 25.12.2002. 
2) Debts for the social security on other statements (not mentioned above) and tax payments;

3) Usual rights of creditors.

In the Law of Bankruptcy of Brazil there is a following order of debts coverage:

1) Debts for salaries and other related payments;

2) Debts for creditors insured by deposits;

3) Debts for taxes and fees;

4) Debts for other creditors (Araujo 2012, 955).

In Russia tax obligations are situated in the third position equally with other creditors (Article 134 Insolvency (Bankruptcy) Act), that is usually being criticized (Laskina 2009, 63-78; Latypova 2004).

It seems to be fair to position the claims of the state equally with the claim of another state. However, in practice it could lead for the abusive behavior of some taxpayers of shifting for more advantageous jurisdictions - "bankruptcy tourism" (Walters, Smith $2009,181-208)^{71}$. The proposal of deciding this conflict of laws in an international treaty will lead for the impairment of rights of creditors only by the fact of the participation of foreign country in bankruptcy case. Thus, reciprocity and respect to the sovereign position considering national priority of the claims of each party is known and is a natural risk of contracting state.

There also should be a question of priority of public claims considering multiple proceedings: parallel or subordinated proceedings.

5. Sanation of a debtor, financial rehabilitation, peaceful agreement in bankruptcy cases with claims of the foreign (BRICS) states.

The issue of financial rehabilitation of the debtor instead of its liquidation, in our opinion, should be the main in bankruptcy case, but differences in national bankruptcy legislations of BRICS countries might not only complicate but block this rehabilitation.

For example, in the Federative Republic of Brazil and South-African Republic the method of netting is applied. Netting is a method of determination of a size of obligations by aggregation, combination and reciprocal offset two or more obligations.

This construction is not complied with Russian and Chinese regulations where there is a challengeable of such agreements. However, the absence of a peaceful agreement limits can be used for the legal application of netting. At the same time, the Law of bankruptcy in China has the provisions about setoffs, changing of a creditor, peaceful agreement and financial rehabilitation.

Considering these issues, there should be harmonization of bankruptcy legislation on a national level together with conflict of laws provision on the international level.

6. The absence of the conditions for the realization of reciprocity and bona fide principles of professional managers, courts, state organs acting for the interests

${ }^{71}$ The draft Federal law No. 615865-5 "On amendments to the Federal law "On insolvency (bankruptcy) of credit organizations" and other legislative acts of the Russian Federation to improve the bankruptcy procedures for credit and other financial institutions, strengthening of responsibility for committing illegal actions on the eve of bankruptcy" (as amended adopted by the state Duma in the first reading 10.02.2012); the Draft Federal law "On cross-border insolvency (bankruptcy"). Accessed November 24. 2017. http:// economy.gov.ru/minec. 
of the treasury. Reciprocity of contracting states appears through the reciprocity and fairness of parties of transboundary bankruptcy cases. Undoubtedly, that for cooperation of the parties there should be unified codification, for example, by the conclusion of a multilateral international treaty of BRICS countries or adoption of recommendations of UNCITRAL for further domestic implementations. For example, since 2000 South Africa has been adopted the recommendations of UNCITRAL; there are two draft laws presented in Russia for the implementation of UNCITRAL regulations, however, they were not adopted in 2009, nor in 2011, nor later.

There is no information of the implementation of UNCITRAL recommendations in China or Brazil.

India actively works for the law of transboundary insolvency and base not only on UNCITRAL documents, but on Memorandum of Council of International Lawyers Association 2005 and on the Draft Law on the Cross-Border Insolvency, developed by American Institute NAFTA ${ }^{72}$.

Also, there are harmonization of the rules for municipal bankruptcy of the contracting states, that are being applied in South Africa and Brazil.

To sum up, there can be a conclusion that format of the international cooperation within BRICS is still non-restricted in its own model about the transboundary inconsistency and might be the positive example for other states and international organizations for the effective settlement of particular questions in respect of public interest states- creditors. This new structure was created for the improvement of the efficiency of the economy each of its member, and detailed rules about sanation, financial rehabilitation, acquittal of uncollected debts, in our opinion, will have not only practical, but preventive character, that would promote the strengthening of the economic connections within BRICS.

\section{References}

Alain, David. 1993. "Preferences of the Tax Authorities and Bankruptcy Law in France". Corporate Insolvency And Rescue: The International Dimension. Dennis Campbell and Anthony E. Collins (eds.). Quoted by: Weiss, Jonathan M. 2010. Tax Claims in Transnational Insolvencies: A "Revenue Rule" Approach. Accessed May 22, 2018. https://www.iiiglobal.org/sites/default/files/Jonathan_Weiss.pdf.

Araujo, A.P. et al. 2012. "The Brazilian bankruptcy law experience." Journal of Corporate Finance, Elsevier vol. 18 (4): 994-1004. https://doi.org/10.1016/j.jcorpfin.2012.03.001.

Baird, Douglas G. 1992. The Elements of Bankruptcy. Westbury, New York: Foundation Press. https://catalog.lib.uchicago.edu/vufind/MyResearch/Storagerequest?bib=1305584\&barcode $=51167270$ \&action $=$ add.

Balz, Manfred. 1996. "The European Convention on Insolvency Proceedings." American Bankruptcy Law Journal 70: 485. https://heinonline.org/HOL/LandingPage?handle=hein.journals/ambank70\&div= 30\&id $=$ \&page $=$.

Bekker, A. 2002. “The State Will Stand in the General Queue of Creditors". Vedomosti, January 29, 2002. (In Russian)

Berdeja-Prieto, Agustin. 1994. "Debt Collateralization and Business Insolvency: A Review of the Mexican Legal System." University of Miami Inter-American Law Review 25(2): 227-282. https://repository.law. miami.edu/cgi/viewcontent.cgi?article $=1406 \&$ context=umialr.

72 Promezhutochnyy otchet Komiteta po reforme konkursnogo zakonodatel'stva, yanvar' 2015. [Interim Report of the Committee on the Reform of Bankruptcy Law]. Accessed November 24, 2017 http:// finmin.nic.in/reports/Interim_Report_BLRC.pdf. 
Borisenkova, Tat'iana V. 2005. "Three Russian Bankruptcy Law: a Balance Private and Public Interests". Arbitrazhnyi i grazhdanskii protsess 9 . http://www.consultant.ru/cons/cgi/online.cgi? req=doc;base=CJ I;n=9894\#012452346662776781. (In Russian)

Borisenkova, Tat'iana V. 2008. “The Ratio of Private and Public Interests at Legal Regulation of Bankruptcy of Legal Entities". Synopsis of PhD. diss., Academy of National Economy. (In Russian)

Brezho, Marina A. 2005. "The Protection of State Interests in Case of Bankruptcy of Unitary Enterprises and Other Commercial Organizations with a Share of State Participation”. Synopsis of PhD diss., Russian Academy of Public Administration. (In Russian)

Day, Barbara K. 2000. "National Conference of Bankruptcy Judges." American Bankruptcy Law Journal 74: 1-45. https://www.iiiglobal.org/sites/default/files/barbara\%20day\%20sovereign.pdf

Dobrovol'skii, A. A. 1914. A Set of General Provisions for Trading and Non-Trading Insolvency. Moscow. (In Russian)

Gerner-Beuerle, Carsten and Michael Schillig. 2010. "The Mysteries of Freedom of Establishment after Cartesio". International \& Comparative Law Quarterly 59 (2): 1-21. https://ssrn.com/abstract=1340964

Goncharov, Maksim V. 2010. "Criminal Liability for Causing Damage to Property by Deception in the Field of Taxation”. PhD. diss., Tambov State University named after G. R. Derzhavin. (In Russian)

Iadrikhinskii, Sergei A. 2015. The Mechanism Providing the Fulfillment of Obligations on Payment of Taxes: Problems of Theory and Practice. Moscow: Infra-M Publ. (In Russian)

Igolkina, Katerina N. 2013. "Collecting the Recovery Forced Fee". PhD diss., Russian State Academy of Justice. (In Russian)

Imykshenova, Evgeniia A. 2005. Methods of Securing Tax Obligations Under the Tax Code of the Russian Federation. Moscow, Iurlitinform Publ. (In Russian)

Jackson, Thomas H. and Anthony T. Kronman. 1979. "Secured Financing and Priorities Among Creditors." Yale Law Journal 88: 1143-1182. https://chicagounbound.uchicago.edu/cgi/viewcontent.cgi?article= $11621 \&$ context=journal_articles.

Jackson, Thomas H. and Robert E. Scott. 1989. "On the Nature of Bankruptcy: An Essay on Bankruptcy Sharing and the Creditors' Bargain”. Virginia Law Review. 75: 155-156. Quoted by: Eisenberg, Theodore. 1989. Commentary on "On the Nature of Bankruptcy": Bankruptcy and Bargaining. Cornell Law Faculty Publications 422. Accessed May 22, 2018. https://scholarship.law.cornell.edu/cgi/viewcontent. cgi? article $=1448 \&$ context $=$ facpub.

Kamlah, Klaus. 1996. “The New German Insolvency Act: Insolvenzordnung”. American Bankruptcy Law Journal 70: 417-420.

Kasnitskaia, Inna Yu. 2008. "Criminally-legal Characteristic of Crimes in the Sphere of Taxation”. PhD diss., Tyumen Law Institute of the Ministry of Internal Affairs of the Russian Federation. (In Russian)

Khimichev, Viktor A. 2005. Protection of the Rights of Creditors in Bankruptcy. Moscow, VoltersKluver Publ. (In Russian)

Koral, Richard L. and Marie-Christine Sordino. 1996. "The New Bankruptcy Reorganization Law in France: Ten Years Later". 70 American Bankruptcy Law Journal 70: 437. Quoted by: Weber, Robert K. 2005. Can the Sauvegarde Reform Save French Bankruptcy Law? A Comparative Look at Chapter 11 and French Bankruptcy Law from an Agency Cost Perspective. Michigan Journal of International Law 27: 257-285. Accessed May 22, 2018. https://digitalcommons.law.utulsa.edu/cgi/viewcontent. cgi?article $=1083 \&$ context $=$ fac_pub.

Lacey, David. 1993. "Preferential Claims of Government in English Insolvency Proceedings". Corporate Insolvency And Rescue: The International Dimension. Kluwer Law and Taxation Publishers. Deventer Boston: 43-58. Quoted by: Morgan (Day), Barbara K. 2000. "Should the Sovereign Be Paid First? A Comparative International Analysis of the Priority for Tax Claims in Bankruptcy. National Conference of Bankruptcy Judges". American Bankruptcy Law Journal 74. Accessed May 25, 2018. https:// www.iiiglobal.org/sites/default/files/barbara\%20day\%20sovereign.pdf.

Laskina, Svetlana O. 2009. “Tax Liabilities in Bankruptcy”. Khoziaistvo i pravo 12: 63-78. (In Russian)

Laskina, Svetlana O. 2010. "Protection of the Legitimate Financial Interests of the State in Case of Bankruptcy of Legal Entities”. PhD diss., Russian Academy of Justice. (In Russian)

Latypova, Elena U. 2004. "The enforcement of the obligation to pay taxes and fees: financial and legal aspect”. PhD. diss., MGIMO University. (In Russian) 
Leibfritz, Willi et al. 1995. “The Tax System of Germany." Tax Notes International 2/6: 465-476.

Letin, A.V. 2003. "Cross-border Insolvency as the Object of the Science of International Private Law". Gosudarstvo i pravo 8: 80-81. (In Russian)

Lopez-Ibor, Rocio A., Artes-Caselles, Joaquin. 2003. "Bankruptcy Proceedings and Government: Should Bankruptcy Law Grant Privileges to the Treasury". Germanworking papers in Law and Economics. Paper 9. Quoted by: Day, Barbara K., Hon. Zulman, Ralph, Hon. Garrity, James. 2005. Report prepared by the Committee on Tax Priorities. Accessed May 22, 2018. https://www.iiiglobal.org/sites/default/ files/barbara\%20day.pdf.

Mokhova, Elena V. 2009. "Doctrine of Primary production Cross-border Insolvency of Legal Entities". PhD diss., Russian Academy of Justice. (In Russian)

Mokhova, Elena V. 2009. The Doctrine of Modified Universalism as the Basis for the Regulation of Crossborder Insolvency: the Division of Authority between Courts of Different States. Moscow, Pashkov dom Publ. (In Russian)

Mokhova, Elena V. 2012. "Centre of Main Interests of the Debtor in Cross-border Insolvency: the Prospects for the Introduction in Russia of New Legal Frameworks". Zakon 10: 111-127. (In Russian)

Mokhova, Elena V. 2013. "Needs and Prospects for Regulating Cross-border Insolvency in the Russian Federation”. Rossiyskoe pravosudie 4: 54-66. (In Russian)

Mokhova, Elena V. 2014. "Cross-border Bankruptcy: Russian Legal Realities and Perspectives”. Zakon 6: 62-73. (In Russian)

Mokhova, Elena V. 2014. "The Appeal in the Russian Court Deals Abroad Bankruptcy of the Debtor. Comment to the Decree of the Presidium of the SAC dated 12.11.2013 No. 10508/13 in the Case of AB Bank SNORAS". Vestnik VAS RF 5: 48-66. (In Russian)

Mucciarelli, Federico M. 2011. Freedom of Reincorporation and the Scope of Corporate Law in the U.S. and the E.U. New York: New York University School of Law. http://dx.doi.org/10.2139/ssrn.1783607.

Mucciarelli, Federico M. 2014. "The Unavoidable Persistence of Forum Shopping in European Insolvency Law”. SSRN, January 7, 2014. http://dx.doi.org/10.2139/ssrn.2375654.

Paulus, Christoph G. 1998. "The New German Insolvency Code”. Texas International Law Journal 33: 141144. https://www.questia.com/library/journal/1P3-28520015/the-new-german-insolvency-code.

Radygin, A. D. et al. 2005. The Institution of Bankruptcy: Development, Problems, Areas of Reforming. Moscow: IEPP-CEPRA Publ. (In Russian)

Rajak, Harry. 1997. “Book review. The law of insolvency”, $2^{\text {nd }}$ ed. International insolvency review 6: 81-84. https://doi.org/10.1002/iir.3940060108.

Romero, Francisco. 2000. “The New Proposed Mexican Bankruptcy Law 26-27”. Paper delivered at the American Bankruptcy Institute 2000 Annual Spring Meeting. Quoted by: Phelan, Robin E., Beckham, Charles A. Jr. 2002. Cross-border insolvency with Mexico. Haynes and Boone (eds.), LLP. III Second Annual International Insolvency Conference Fordham University Law School: 17. Accessed May 22, 2018. https://www.iiiglobal.org/sites/default/files/3-_Cross_Border_Insolvency_with_Mexico.pdf.

Rossiyskaya gazeta. 2002. "Why rejected bankruptcy Law". Rossiyskaya gazeta, August 07, 2002. (In Russian)

Rowat, Malcolm and Jose Astigarraga. 1999. Latin American Insolvency Systems, A Comparative Assessment. Washington, D.C.: World Bank Technical Paper. http://documents.worldbank.org/curated/ en/692711468756991896/pdf/multi-page.pdf.

Sánchez-Mejorada, Carlos. 2000. Remarks at The American Law Institute, Seventy-Seventh Annual Meeting. Washington, D.C. Quoted by: Morgan (Day), Barbara K. 2000. "Should the Sovereign Be Paid First? A Comparative International Analysis of the Priority for Tax Claims in Bankruptcy. National Conference of Bankruptcy Judges". American Bankruptcy Law Journal 74. Accessed May 25, 2018. https:// www.iiiglobal.org/sites/default/files/barbara\%20day\%20sovereign.pdf.

Savel'eva, Tat'iana A. 1998. "Collateral Relationships and Their Effect Upon the Legislation of the Russian Federation”. PhD. diss., Tomsk State University. (In Russian)

Serlooten, Patrick. 2000. "Le Tresor Public, Creancier de l'Entreprise en Difficulte”. La Semaine Juridique Entreprises Et Affaires 1: 24-28.

Shershenevich, Gabriel’ F. 1890. The Doctrine of Insolvency. Kazan’. (In Russian)

Simpson, Jeffrey J. 1999. "Crown Possessory Liens under the Bankruptcy and Insolvency Act." Commercial Insolvency Reporter 12 (1). 
Sobina, Liudmila Yu. 2012. Recognition of Foreign Bankruptcies in the International Private Law. Moscow: Statut Publ. (In Russian)

Studentsova, O. A. "Legal Regulation of Bankruptcy Procedures According to the Legislation of Russia and USA: Comparative Analysis". PhD diss., Russian State University for the Humanities. (In Russian)

Swart, B. H. 1990. "Die rol van.n concursus creditorum in die Suid-Afrikaanse insolvensiereg". Dr. Sc. diss., Universiteit van Pretoria.

Too, Fancy C. 2015. "A Comparative Analysis Of Corporate Insolvency Laws: Which Is The Best Option For Kenya?” PhD diss., Nottingham Trent University. https://core.ac.uk/download/pdf/42393304.pdf.

Tron, Manuel E. 1997. "The Mexican Tax System”. Mexican Law Library Commercial Codes, edited by William D. Signet, 749-747. Eagan, West Publishing Company.

Trushnikov, Sergei S. 2006. The Proceedings in Insolvency in Russia and Germany. St. Petersburg: St. Petersburg University Press. (In Russian)

Verstova, Margarita E. "Conceptual frameworks for Tax and Law Enforcement Authorities of the Performance by Taxpayers of Their Duties". Dr Sc. diss., Academy of Management of the Ministry of Internal Affairs of Russia. (In Russian)

Vitrianskii, Vasilii V. 2003. "New in the Legal Regulation of Insolvency (Bankruptcy)". Khoziaistvo i pravo 1: 3-21. (In Russian)

Walters, A. and A. Smith. 2009. "Bankruptcy Tourism" Under the EC Regulation on Insolvency Proceedings: A View from England and Wales”. International Insolvency Review 19 (3): 181-208.

Wood, Philip R. 1995. "Principles of International Insolvency. Part 1". Principles Of International Insolvency. 94-103. https://onlinelibrary.wiley.com/doi/pdf/10.1002/iir.3940040105.

Wymeersch, Eddy. 2003. “The Transfer of the Company's Seat in European Company Law". SSRN, April 1, 2003. https://ssrn.com/abstract=384802.

Ziegel, Jacob S. 1996. “Canada’s Phased-In Bankruptcy Law Reform”. American Bankruptcy Law Journal 70: 383409. https://heinonline.org/HOL/LandingPage?handle=hein.journals/ambank70\&div=26\&id=\&page=.

Received: September 30, 2018

Accepted: May 17, 2019

Author's information:

Stanislav S. Izvekov — PhD in Law; ss.izvekov@gmail.com 